\title{
Packed cell volume, haemoglobin, and oxygen saturation changes in healthy smokers and non-smokers
}

\author{
VG TIRLAPUR, KIMANI GICHERU, BM CHARALAMBOUS, PJ EVANS, MA MIR
}

From the Department of Medicine, University Hospital of Wales, Cardiff

ABSTRACT We have investigated the relationship between cigarette smoking, packed cell volume, haemoglobin concentration, and arterial oxygen saturation $\left(\mathrm{SaO}_{2}\right)$ in 114 non-smokers, 66 light smokers (1-20 cigarettes a day), and 50 heavy smokers (over 20 cigarettes a day) aged 20-75 years. Packed cell volume was greater in female heavy smokers $(p<0.001)$ over 40 years of age and in all female smokers over 60 years $(p<0.001)$ than in non-smoking contemporaries. Haemoglobin concentrations were higher in $40-59$ year old female heavy smokers $(p<0.05)$ and in male and female light $(\mathrm{p}<0.05)$ and heavy smokers $(\mathrm{p}<0.001)$ over 60 years of age than in non-smoking contemporaries. $\mathrm{SaO}_{2}$ was lower in 20-39 year old male heavy smokers $(\mathrm{p}<0.02)$ and female $(\mathrm{p}<0.05)$ light smokers and also in 40-59 year old male light and heavy smokers $(p<0.001)$ and female light smokers $(p<0.02)$ than in non-smoking contemporaries. It was also lower in female light $(\mathrm{p}<0.05)$ and heavy $(\mathrm{p}<0.02)$ smokers over 60 years, whereas it was higher in male light smokers over $60(\mathrm{p}<0.001)$. Changes in $\mathrm{SaO}_{2}$ were seen at a younger age than changes in haemoglobin concentration and packed cell volume.

Increase in packed cell volume in healthy smokers is caused by increase in erythrocyte mass, ${ }^{1-3}$ while arterial oxygen saturation $\left(\mathrm{SaO}_{2}\right)$ appears to be the most important determinant of the erythropoietic response. ${ }^{4}$ Cigarette smoking has been shown to determine the degreee of secondary polycythaemia in patients with hypoxic chronic obstructive pulmonary disease, ${ }^{5}$ but the relationship between cigarette smoking, $\mathrm{SaO}_{2}$ and haematological indices in healthy subjects has not been studied. We designed this study to investigate the interactions between smoking habits, age, sex, haemoglobin concentration, packed cell volume and $\mathrm{SaO}_{2}$ in healthy subjects.

\section{Methods}

Two hundred and thirty healthy hospital employees, medical students, and nurses aged 20-75 years were studied after we had obtained their informed consent and approval of the local ethical committee. One hundred and fourteen were non-smokers, 66

Address for reprint requests: Dr VG Tirlapur, Department of Medicine, University Hospital of Wales, Heath Park, Cardiff CF4 4XW

Accepted 16 May 1983 were light smokers (1-20 cigarettes per day), and 50 were heavy smokers ( $>20$ cigarettes per day); the table shows the age distribution of each group. All smokers inhaled the tobacco smoke regularly but the frequency and duration of inhalation was not assessed. Subjects were studied between 09.00 and 12.00 after 60 minutes' abstinence from smoking. Venous blood was sampled for measurement of haemoglobin and packed cell volume. Haemoglobin was measured by Cyan-Met (model S) and the packed cell volume was calculated by a Coulter counter computer after the red cell count and mean corpuscular volume had been obtained. $\mathrm{SaO}_{2}$ was measured by an ear oximeter (Hewlett-Packard, 47201A). Results were analysed by Students's unpaired $t$ test.

\section{Results}

The results of haemoglobin, packed cell volume, and $\mathrm{SaO}_{2}$ measurements are summarised in the figure, where light and heavy smokers are compared with non-smokers of the same age and sex.

Mean haemoglobin concentration was increased in female heavy smokers aged 40-59 years ( $\mathrm{p}<$ $0.05)$ and in male and female light $(\mathrm{p}<0.05)$ and 

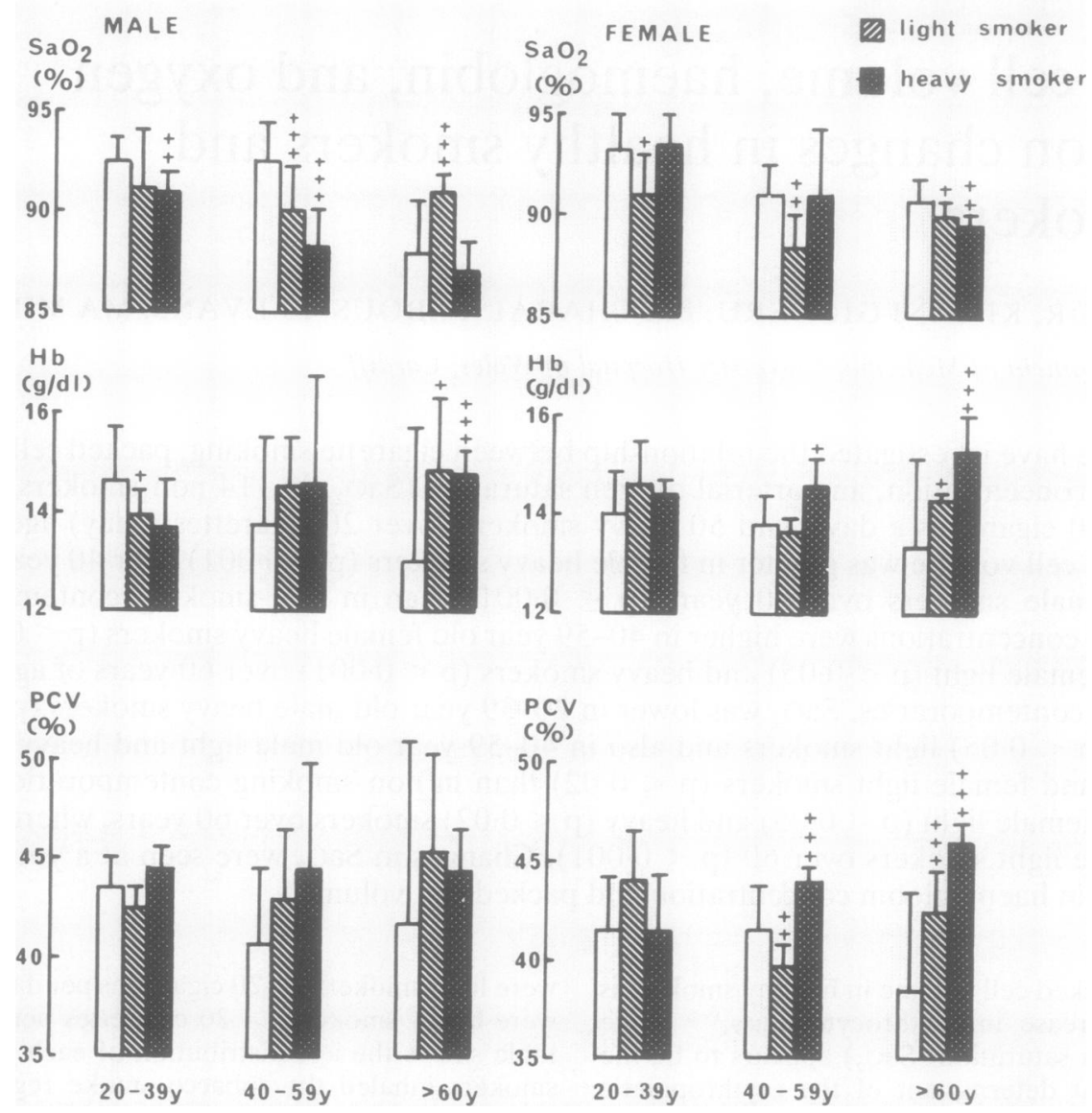

Oxygen saturation $\left(\mathrm{SaO}_{2}\right)$, haemoglobin $(\mathrm{Hb})$, and packed cell volume (PCV) values in 230 healthy male and female non-smokers and light and heavy smokers. Light and heavy smokers were compared with the non-smokers within same age and sex group. Data are shown as means and standard deviations

Significant differences: $+\rightarrow p<0.05 ;+\rightarrow p<0.02 ; \stackrel{+}{+} \rightarrow p<0.001$.

heavy ( $\mathrm{p}<0.001$ ) smokers over 60 but reduced in 20-39 year old male light smokers $(p<0.05)$ when compared with non-smoking contemporaries. In all other groups there were no significant differences between smokers and non-smokers. Haemoglobin concentration increased with advancing age in heavy smokers of both sexes and was significantly higher in male and female heavy smokers over 60 than in younger heavy smokers. There were no significant differences among non-smokers when age groups 0

Distribution of the 230 healthy subjects subdivided according to age, sex, and smoking habits

\begin{tabular}{|c|c|c|c|c|c|c|c|c|c|}
\hline \multirow[b]{2}{*}{ Age (y): } & \multicolumn{3}{|c|}{ Non-smokers (114) } & \multicolumn{3}{|c|}{$\begin{array}{l}\text { Light smokers (66) } \\
\text { (1-20 cigarettes a day) }\end{array}$} & \multicolumn{3}{|c|}{$\begin{array}{l}\text { Heavy smokers }(50) \\
(>20 \text { cigarettes a day) }\end{array}$} \\
\hline & $20-39$ & $40-59$ & $60-75$ & $20-39$ & $40-59$ & $60-75$ & $20-39$ & $40-59$ & $60-75$ \\
\hline $\begin{array}{l}\text { Men (126) } \\
\text { Women (104) }\end{array}$ & $\begin{array}{l}20 \\
20\end{array}$ & $\begin{array}{l}18 \\
20\end{array}$ & $\begin{array}{l}18 \\
18\end{array}$ & $\begin{array}{r}9 \\
12\end{array}$ & $\begin{array}{r}18 \\
9\end{array}$ & $\begin{array}{l}9 \\
9\end{array}$ & $\begin{array}{l}7 \\
6\end{array}$ & $\begin{array}{r}15 \\
6\end{array}$ & $\begin{array}{r}12 \\
4\end{array}$ \\
\hline
\end{tabular}


were compared. Mean packed cell volume was higher in female heavy smokers $(\mathrm{p}<0.001)$ over 40 and also in all female $(p<0.001)$ smokers over 60 than in non-smokers. In 40-59 year old female light smokers $(p<0.02)$ the packed cell volume was significantly lower than in non-smokers. No other significant differences in packed cell volume were observed.

Arterial oxygen saturation $\left(\mathrm{SaO}_{2}\right)$ was lower in non-smoking contemporaries than in 20-39 year old male heavy $(\mathrm{p}<0.02)$ and female light $(\mathrm{p}<$ $0.05)$ smokers, 40-59 year old male light $(\mathrm{p}<$ $0.001)$ and heavy smokers $(p<0.001)$, and female light $(\mathrm{p}<0.05)$ and heavy $(\mathrm{p}<0.02)$ smokers over 60 , but it was higher in male light smokers over 60 $(p<0.001)$. No other significant differences between smokers and non-smokers were observed.

\section{Discussion}

The effect of smoking on haemoglobin and packed cell volume is controversial. Female smokers have been reported to have a higher haemoglobin concentration than non-smokers whereas male smokers over 50 have been found to have lower haemoglobin concentrations than non-smokers. ${ }^{6}$ In subjects over 50 we found higher haemoglobin concentrations in smokers of both sexes than in non-smokers. Harrison $e t a l^{7}$ found that smokers of both sexes had a greater packed cell volume than non-smokers, irrespective of age. Our results show a tendency for packed cell volume to be higher in smokers than non-smokers, which reaches significance in older women. The packed cell volume values in our smokers showed a slight increase with advancing age but these differences were not significant, possibly because of the large variability observed in this study, which may in part be related to differences in inhalation behaviour and in frequency and duration of smoking in the subjects studied. ${ }^{8}$

In our study $\mathrm{SaO}_{2}$ was generally found to be lower in smokers than in non-smokers. It was reduced in the 20-39 year old male heavy smokers and female light smokers at an age when no changes in packed cell volume and haemoglobin were observed. We believe that reduced $\mathrm{SaO}_{2}$ in smokers is probably due to increased carbon monoxide levels in the blood.9 In smokers increased levels of carboxyhaemoglobin have been shown to be associated with an increase in the red cell volume and reduction in the plasma volume, or both. ${ }^{10}$ Some of our findings were paradoxical-for example, $\mathrm{SaO}_{2}$ was increased in the light smokers over 60 and haemoglobin concentrations in 20-39 year old male smokers. These results could be related to chance variation in inhalation habits and duration and frequency of smoking in these groups. ${ }^{811}$

In conclusion, this study shows that smokers generally show mild erythrocytosis similar to that seen in relative polycythaemia (normal red cell volume), particularly in older people, when they are compared with non-smoking contemporaries. Changes in $\mathrm{SaO}_{2}$ in smokers are seen at an earlier age than changes in haemoglobin concentration and packed cell volume.

\section{References}

' Okuno T. Smoking and blood changes. JAMA 1973;225:1387-8.

${ }^{2}$ Sagone AL, Lawrence T, Bakerzak SP. Effect of smoking on tissue oxygen supply. Blood 1973;6:845-51.

${ }^{3}$ Sagone AL, Bakerzak SP. Smoking as a cause of erythrocytosis. Ann Intern Med 1975;82:512-5.

${ }^{4}$ Weil JV, Jamieson GT, Brown DW, Grover RF. The red cell mass-arterial oxygen relationship in normal man. J Clin Invest 1968;47:1627-39.

5 Calverley PMA, Leggett RJ, McElderry L, Flenley DC. Cigarette smoking and secondary polycythemia in hypoxic cor pulmonale. Am Rev Respir Dis 1982;125:507-10.

- Helman N, Lawrence S, Rubenstein LS. The effect of age, sex and smoking on erythrocytes and leukocytes. $\mathbf{A m ~ J}$ Clin Pathol 1975;63:35-44.

${ }^{7}$ Harrison MJG, Pollock S, Thomas D, Marshall J. Haematocrit, hypertension and smoking in patients with transient ischaemic attacks and in age and sex matched controls. J Neurol Neurosurg Psychiatry 1982;45:550-1.

${ }^{8}$ Yen Do Ho, Spence VA, Moody JP, Walker WF. Why smoke fewer cigarettes? Br Med J 1982;284:1905-7.

9 Vanuxem D, Guillot C, Grimaud C. Tabagisme et monoxyde de carbone. Respiration 1941;40:136-41.

${ }^{10}$ Smith JR, Landow SA. Smokers' polycythaemia. $N$ Engl J Med 1978;298:6-10.

" Russell MA, Wilson C, Taylor C, Barker CD. Smoking habits of men and women. Br Med J 1980;281:17. 